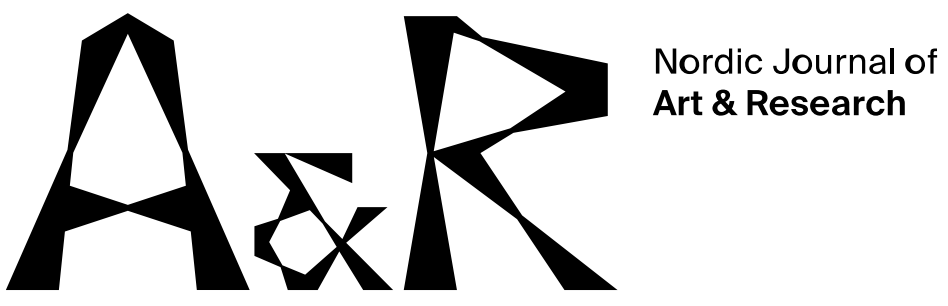

\title{
Form, exform, and information in public space
}

\author{
Mikkel B. Tin ${ }^{1}$ \\ University of South-Eastern Norway
}

\begin{abstract}
If the urban tissue can be compared to a verbal text, how appropriate, then, do the linguistic disciplines prove in urban studies? This article briefly shows how morphology (Oliveira, 2016) and semantics (Benveniste, 1971) help us understand the city's physical structures as well as the meaning these structures embody. Then follows a more substantial discussion of poetics (Ricœur, 1991) and its relevance to research on art in public space. An artistic intervention in public space may in fact appear as a poetic trope within the prosaic context of the city (De Certeau, 1988). Interrupting the smooth run of the urban machinery, it may re-inform what has become redundant. Thus, Marianne Heske's House of Commons not only questions our definitions of form and exform (Bourriaud, 2016); in-forming an ex-form, it also questions the power of definition and other power structures inherent in the cityscape.
\end{abstract}

Keywords: Urban morphology, semantics, poetics, tropes, exform, Marianne Heske, power structures

\section{From form to information}

Art in public space may refer to a variety of things: an equestrian statue of a ruler centrally placed in front of a palace and intended to last for centuries, or a painting that tours a few days on the side of a subway car before it is removed by the 
Mikkel B. Tin. Form, exform, and information in public space.

authorities. But art in public space can also be a performance or an intervention, which need not take place in urban environments; public space may also be virtual space or wild nature.

Nevertheless, diverse as it may be, art in public space is distinctive in that it intervenes in a specific and public environment. The interaction thus established between artwork and context is constitutive of this kind of art. Other kinds of art do not depend essentially on specific contexts, revealing their meaning as autonomous objects.

In the following, I nonetheless limit my argument to the urban environment. And I will insist on this urban environment being a context, namely an existing text as the context for the artistic intervention. The notions of text and context are not accidental. My contention is that the urban environment can be seen as a text consisting of formal components assembled into meaningful wholes according to certain syntactic rules. It is these different rules that account for the obvious differences between urban environments like, for instance, Berlin and Prague, or between the old town of Prague and its suburbs. The constituent forms are different, and so is the information conveyed by their syntactical combinations.

The apparent parallel between verbal language and the urban environment suggests that certain procedures developed to analyse verbal texts may be applicable to urban texts as well. Indeed, my intention in the following is to discuss the relevance to art in public space of three classical disciplines within linguistics, namely morphology, semantics, and poetics. Can these three disciplines, traditionally concerned with verbal texts, be useful when setting out to understand artistic research that aims at public art? I will first carry out my discussion on a theoretical level, briefly presenting the three mentioned disciplines and discussing their relevance to public art and the information it communicates; and subsequently test my findings in a concrete example, namely Marianne Heske's House of Commons from 2015.

\section{Morphology}

In Greek, the word morphé means 'form'. Morphology, consequently, means something like the 'study of forms'. In linguistics, morphology is the discipline that studies the formal constituents of language. A piece of language, oral or written, will be broken down into its constituents: sentences, words, sounds. These constituent forms are the stuff of grammars, dictionaries and works on phonology. In such works, forms are studied in relation to other forms in an abstract system, detached from their communicative function in a concrete text. Basically, morphology provides a 
Mikkel B. Tin. Form, exform, and information in public space.

classificatory system of all the formal elements of language without ever taking into account the information we hope to communicate when using language practically.

The morphological approach has been applied in the branch of urban studies named urban morphology. For more than 50 years already, this discipline has analysed the formal elements of urban environments. Urban morphology deals with exactly such environments where we are likely to find art in public space, and that makes it particularly interesting to our purpose.

In his authoritative presentation of urban morphology, the Portuguese morphologist Vítor Oliveira suggests the following succinct definitions: Urban morphology is 'the study of urban forms, and of the agents and processes responsible for their transformation'. Urban forms, in their turn, are 'the main physical elements that structure and shape the city - urban tissues, streets (and squares), urban plots, buildings, to name the most important' (Oliveira, 2016, p. 2). The physical aspect is emphasized already in the subtitle of the book: "An introduction to the study of the physical form of cities". Karl Kropf, in The Handbook of Urban Morphology also mentions the physical aspect of urban form, yet not as the only aspect: "The aim of urban morphology is to contribute to our understanding of the built environment as a complex physical object, a cultural artefact and quasi-natural phenomenon similar to language." (Kropf, 2017, p. 9) We see that he emphasizes the similarity between urban and linguistic morphology.

Like linguistic morphology, proceeding from a meaningful piece of discourse, urban morphology, thus takes its starting point in a given urban tissue and subjects this tissue to a morphological analysis. For the most part, however, urban morphology carries out its analyses on maps. According to the level of resolution, i.e., the scale of the map, the morphological analysis will proceed from the street level, the plot level, or the building level. By repeating this procedure on maps of the same urban tissue drawn at different moments in history, the morphological transformations will appear as superimposed layers. Maps, therefore, can be seen as palimpsests. Originally the Greek work for a piece of parchment on which previous layers of inscription have been erased to accommodate new inscriptions, a palimpsest in urban morphology designates an urban tissue where the traces of varying urban strategies of the past appear more or less distinctly through later layers. Such is the case with Paris, for instance, where Baron Hausmann imposed on the network of medieval streets and alleys a grid of avenues, connecting the nodal points of modern centralized France. These two layers are still clearly visible on the Paris map. 
Mikkel B. Tin. Form, exform, and information in public space.

Like linguistic morphology, urban morphology aims at regularities, and these regularities appear through quantitative and statistical methods, largely based on recently developed software. The regularities typically concern 'the relationships between space, movement and land use patterns' (Oliveira, 2016, p. 120). They can be traced back to the varying policies of agents such as developers, architects, city planners, politicians. Baron Hausmann was one such planner. These agents, therefore, are also those believed to have the capacity to transform existing patterns or design new ones. Urban morphology has the ambition to provide the necessary knowledge on which to base such policies. Urban morphologists are well aware of the complexity of the urban environment, and the multiple factors that contribute to form and transform it, and ultimately inform it. Yet social and cultural qualities of the urban environment are taken into account only insofar as they can be measured quantitatively. The ideological implications of the urban design lies beyond the scope of urban morphology, including the life quality of the citizens. When accessibility, connectivity, intelligibility, and diversity are important in urban morphology, it is because they can be measured by its quantitative methods. The assumption is that there is a link between urban form and such urban features, so that for instance the degree of connectivity depends on the number of street crossings.

According to established criteria, for instance the ratio between building heights and street widths, or population density, the morphological analysis may define a street as residential or commercial or administrative, while other criteria will define the population of a neighbourhood as homogeneous or heterogeneous. Distinguishing different 'character areas', these features are indicated in different colours on the morphological maps. In urban morphology, however, form is physical form and not an integrated part of the citizen's lived experience of inhabiting the city. What urban forms mean to the inhabitants is as irrelevant to urban morphology as is the meaning of a text to linguistic morphology. Urban morphology does not explain how form may produce information.

\section{Semantics}

The exclusive focus on form is perceived as a shortcoming by some researchers within urban studies as well as linguistics. In a discussion of the different levels in linguistic investigation, the French linguist Emile Benveniste (1902-1976) distinguishes between the constitutive form and the integrative meaning of a given sentence (Benveniste, 1971, p. 106). In the investigation of the sentence, there are in fact two ways to go: not only downwards, analytically, taking the sentence apart in view of its formal elements, but also upwards, semantically, linking sentences together to discover the emergence of meaningful units: "This is the point: the 
Mikkel B. Tin. Form, exform, and information in public space.

analysis discloses the formal constituents; the integration discloses meaningful units. ... The form of a linguistic unit is defined as its capacity for being broken down into constituents of a lower level. The meaning of a linguistic unit is defined as its capacity to integrate a unit of a higher level." (Benveniste, 1971 p. 107)

Benveniste's conclusion concerns the sentence as a meaningful whole; it might have concerned the street as well: 'The sentence, an undefined creation of limitless variety, is the very life of human speech in action. We conclude from this that with the sentence we leave the domain of language as a system of signs and enter into another universe, that of language as an instrument of communication, whose expression is discourse.' (Benveniste, 1971, p. 110) We have, in short, two different linguistics. On the one hand, the discipline that conceives language as an ensemble of formal signs, identifiable by rigorous procedures that order them in classes, structures, and systems; and on the other, the discipline that sees language as an essential tool in living communication.

The morphological analysis is essential to understand the forms and formal combinations that constitute a text, whether verbal or urban; yet such analysis is unable to explain why these concrete forms are combined according to exactly these rules, and how a given combination becomes informative. Nevertheless, if the urban environment is to provide the context of an artistic intervention, the researcher/artist cannot ignore the formal elements that constitute this context; but the researcher/artist must also know what kind of information is materialized in this environment: Is it the rule of international banking, housing for low-income populations, measures to touristify the historical centre, or to ensure the efficient transportation of commuters?

As concrete realities, urban environments as well as written texts are charged with information. The understanding of this information, however, is not a morphological but a semantic challenge.

While morphé means 'form', the Greek sema means 'sign'. So if morphology is the study of forms, semantics is the study of signs, namely in their capacity to signify. The semantic approach may take its starting point in the elementary components identified by morphological analysis; its focus is the ways these components are joined into wholes that refer meaningfully to our world. Semantics studies how forms are in-formed so as to create and communicate information.

Morphologically, forms are studied and defined negatively, namely by the way they differ from each other. Semantically, forms are studied in their positive capacity to 
Mikkel B. Tin. Form, exform, and information in public space.

relate to the world we live in. The dictionary defines the basic, and abstract, signification of the word 'house'; but when I say 'The house where I grew up' I make my words relate concretely to my life, I make them come to life: they become semantically informative. Exactly the same happens when, from having been a house-form on the architect's desk, the house integrates its context and becomes the concrete environment of my childhood and thereby a meaningful component of my world.

Any world consists of a great many routines; and most of our communication has a purely pragmatic aim. We tend to take each other and our environment for granted. When we move into a housing estate, the architect has decided not only that we will have a sofa and a television set but also where we are to place them; and once they are placed we sit down and watch TV, and it is clear what we refer to when speaking of 'the sofa' and 'the TV'. Likewise, the city planner has decided that we need a car and a supermarket, and after a while we know what 'the car' and 'the supermarket' refer to concretely, and how to connect the two. We, as users, expect the urban text to be univocal and transparent, and the bus to take us to the office every morning at 07:23, in accordance with the timetable at the bus-stop.

What distinguishes our everyday life quite generally is in fact its redundancy: frictionless, everyday life may attain a high degree of practical efficiency but provides little or no semantic information. Suburban dormitories are extreme cases of urban redundancy, and they owe their name to the lack of information they provide; on a global scale, fancy malls in the city-centre are perhaps even more uniform and predictable than dormitories. On the other hand, one can say that urban morphology is possible only because urban forms are repeated over and over again in recurrent combinations; so we can classify them and expect them to have the same meaning in whatever context they may appear.

Our everyday urban context is full of forms but poor in information. In his hermeneutics, the French philosopher Paul Ricœur (1913-2005) works primarily on written texts, and in his work The Rule of Metaphor: Multi-disciplinary studies of the creation of meaning in language, he particularly studies the function of metaphor and the reason for its occurrence: 'It could be that the everyday reference to the real must be abolished in order that another sort of reference to other dimensions of reality might be liberated.' (Ricœur, 1991, p. 145) Can it be that art in public space similarly has the ambition to liberate another sort of reference to other dimensions of reality, and that in order to do so it first has to question the everyday reference to 'the real'? 
Mikkel B. Tin. Form, exform, and information in public space.

\section{Poetics}

When art in public space is this statue of the ruler on his horse, cast in bronze and elevated on its plinth in front of the royal palace, it does not question the everyday reference to a centralized and hierarchical urban reality; quite the contrary, it is erected to confirm it. A lot of form, yet more conformity than surprise, and therefore scarce semantic information when we happen to pass by.

In other cases, however, art in public space is more ambitious and does set out to recharge the prosaic text of the city semantically by challenging its redundancy. Ricœur insists on 'the instructive and informative functions linked to a bringingtogether of terms that first surprises, then bewilders, and finally uncovers a relationship hidden beneath the paradox.' (Ricœur, 1991, p. 27) Such informative functions, where a foreign element is inserted into a familiar context, are metaphorical. Generally, metaphor bears information because, as a short circuit of categories, it 'redescribes' reality.

The function of metaphor is in fact not only to provoke surprise in an otherwise predictable text; like metaphor in the linearity of the text, art may intervene in the pragmatic linearity of the streetscape to stimulate our active and creative interpretative effort. What we thought was univocal turns out to be plurivocal, and we must try out new ways of understanding. This effort to release the latent meaning of the text, to 'vivify' it, is 'the "soul" of interpretation' (Ricœur, 1991, p. 303) and contributes to an existential effort to understand. As reinterpretations of our world, metaphors contribute to an ongoing process of in-formation which is basic in human existence. Ricœur has dedicated his work to hermeneutics, very much in the existentialist tradition, and we see that the potential he ascribes to metaphor is to revive what has become inert commonplace.

The French title of Ricœur's book is in fact La métaphore vive, something like 'the live metaphor'. Yet metaphor is just one of several tactics to suggest something other than what is stated. 'In all the tactics within this strategy, the trick consists in giving indicators that point towards the second level of meaning.' (Ricœur, 1991, p. 95) In works of poetics, such vivifying tactics are all named tropes. Etymologically, tropos in Greek means 'turn'. A common characteristic of the various kinds of tropes is that they divert the linear progression of the text. They themselves are textual constructions in which a word or an expression is turned away from its proper meaning. While the prosaic text aims at a univocal and efficient reception of the message, and therefore requires logical coherence, a trope is made and meant to provoke bewilderment first and, subsequently, new information. 
Mikkel B. Tin. Form, exform, and information in public space.

\section{Michel de Certeau and the poetics of everyday practice}

A now classical example of a trope in the urban text is the pedestrian in the city when, instead of continuing forwards on the sidewalk, as the city planner expects him to, he unexpectedly decides to cross the street. By thus turning instead of going straight, the flâneur performs a turn, a trope. The French philosopher Michel de Certeau (1925-1986) develops this pedestrian trope in The Practice of Everyday Life in a very suggestive parallel between the verbal and the urban text: 'The walking of passers-by offers a series of turns (tours) and detours that can be compared to "turns of phrase" or "stylistic figures." There is a rhetoric of walking. The art of "turning" phrases finds an equivalent in an art of composing a path (tourner un parcours).' (Certeau, 1988, p. 100) What Michel de Certeau thus detects in the city are the individual and more or less deviant interpretations of its urban layout that we perform on a daily basis.

The parallel between verbal and urban texts also permits Michel de Certeau to reveal an inherent tension between the univocity of the system and the semantic overlays of urban practice: '... the geometrical space of urbanists and architects seems to have the status of the "proper meaning" constructed by grammarians and linguists in order to have a normal and normative level to which they can compare the drifting of 'figurative" language.' (Certeau, 1988 p. 100)

Like Ricœur, Michel de Certeau sees the 'figurative language' with its tropes as a variety of tactics - more or less creative moves in an urban tissue which was designed by the city planners according to strategies of power. Crucial in Michel de Certeau's work is the distinction he makes between the strategies of power and the tactics of the weak. While the strategies of power are based on the power of definition, and first of all on property and hence the right to define what is 'proper', tactics of the weak appear in the cracks between properties, improvised and ephemeral moves that power can neither foresee nor prevent. Such moves are attempts by the 'un-propertied' to re-appropriate the urban tissue, pushed as they are into an 'indefinite process of being absent and in search of a proper' (Certeau, 1988, p. 103).

Michel de Certeau mentions the 'dancing graphics whose fleeting apparitions are accompanied by the rumble of subway trains: New York graffiti' (Certeau, 1988, p. 102). But there are other tactics: within the straight rationality of the urban text, Michel de Certeau points out entire 'forests of gestures' whose 'rhetorical transplantation carries away and displaces the analytical, coherent proper meanings of urbanism; it constitutes a "wandering of the semantic" produced by masses that 
Mikkel B. Tin. Form, exform, and information in public space.

make some parts of the city disappear and exaggerate others, distorting it, fragmenting it, and diverting it from its immobile order.' (Certeau, 1988, p. 102)

At a certain point in his book, Michel de Certeau finds himself on top of the World Trade Center in New York. He describes the pleasure he feels at observing the city from above, overlooking this 'most immoderate of human texts'. And he asks himself if his pleasure is not caused by an overview that 'makes the complexity of the city readable, and immobilizes its opaque mobility in a transparent text' (Certeau, 1988, p. 92). And, in fact, if the New York text, from this altitude, seems readable and transparent, it is precisely because the city appears as a map from which the complexities of human life have been eliminated; the city appears as a 'totalizing stage' that retains the physical form of urban morphology, but misses the meaning with which it is informed in the lives of the inhabitants.

Eventually, in 'an Icarian fall', Michel de Certeau re-descends the tower's 1370 foot, and re-adopts the pedestrian's limited view on the streetscape. Transparency is replaced by opacity. But whilst the map only maps immobile space in lifeless abstraction, time and movement return when the city is experienced by embodied citizens: 'Their story begins on ground level, with footsteps.' (Certeau, 1988, p. 97)

Thus, our approach to the city, says Michel de Certeau, can be 'either seeing (the knowledge of an order of places) or going (spatializing actions). Either it presents a tableau ("there are..."), or it organizes movements ("you enter, you go across, you turn...")' (Certeau, 1988, p. 119). The choice between these two approaches is linked to the question of property: Those who own property think strategically to defend a given order of places, those who have no property think tactically in terms of spatializing actions. The city always already consists of properties in the hands of the powerful; but those who practice the city on a daily basis, without being proprietors, have the power to reinterpret and ultimately transform it through the movements they perform.

Michel de Certeau's distinction between these two ways of experiencing the city, on the one hand by seeing it at a distance, as an order of places, on the other hand by going into it, performing spatializing actions, seems relevant to research as public art: While seeing represents the analytical approach, with a focus on morphological form as well as semantic information, going involves an integrative approach, aiming at synthesizing not only existing semantic information but also, and more essentially, the transformations provoked by poetic tropes. While the seeing approach, mapping space, is spatial, the going approach, with its spatializing actions, is temporal in that it 
Mikkel B. Tin. Form, exform, and information in public space.

reveals formation and transformation over time caused by non-artistic and, more specifically, artistic interventions.

\section{Marianne Heske informing her House of Commons}

Redundancy characterizes not only the urban environment, it is at work in rural environments as well. In fact, any environment may turn redundant when a life-world is reduced to commonplace. And we tend to reduce even our own life-worlds to commonplaces as long as we take them for granted: here the petrol station, there the bus stop, and over there IKEA. Forms in well-known narratives, but little information. After a rapid morphological survey, we switch off our interpretative effort.

Already in 1980, Marianne Heske had moved a small, abandoned log building, Gjerde-løa, a small barn, from the Norwegian West Coast to the Centre Georges Pompidou in Paris and, after a year, brought it back again. In his text 'Marianne Heske or The Art of Relocation', Nicolas Bourriaud, who published his Relational Aesthetics in 1998, discusses the implications of such 'relocation': 'Project Gjerdeloa presents itself as a meeting point, as a relational work before its time. It is not only about the transition of an object from one point to another, more importantly it is about the confrontation between two human groups.' (Bourriaud in Wendt, 2010, p. 49) Relocation involves a new relation between two human groups; a relation that turns out to confront two incongruent discourses. Heske herself had characterized the building as 'a concrete, tangible medium, which serves to focus attention on our way of thinking and on our ideas. By moving it from one environment and culture to another, I wanted to compare the responses of people from different cultures. ... After all, the main objective of the project was precisely to focus attention on how people regard the hut in different ways, depending on the context in which they see it. There would be little point in moving the hut into an abstract art scene for example.' (Heske, 1984, unpaginated)

Many years later, Heske again carried out the relocation of an abandoned building, again transferring it like a metaphor from one discursive order to another. As long as the little red house stood by the E18 highway at Hobøl, it signified a no longer functional past - like other such houses along other highways. It no doubt was a house, but it was abandoned, and it negated those qualities that made it worthy of its name: it did not house anybody, it was neither a home nor a household. According to the prevailing narrative, it was decay, waste in the way of the enlargement of the highway that links Norway to the continent. When Marianne Heske, in 2015, decided to move it from the countryside to the very heart of the capital, and erect it just in front 
Mikkel B. Tin. Form, exform, and information in public space.

of the parliament, she set out to 'recycle putative waste and make it a source of energy' (Bourriaud, 2016, p. X).

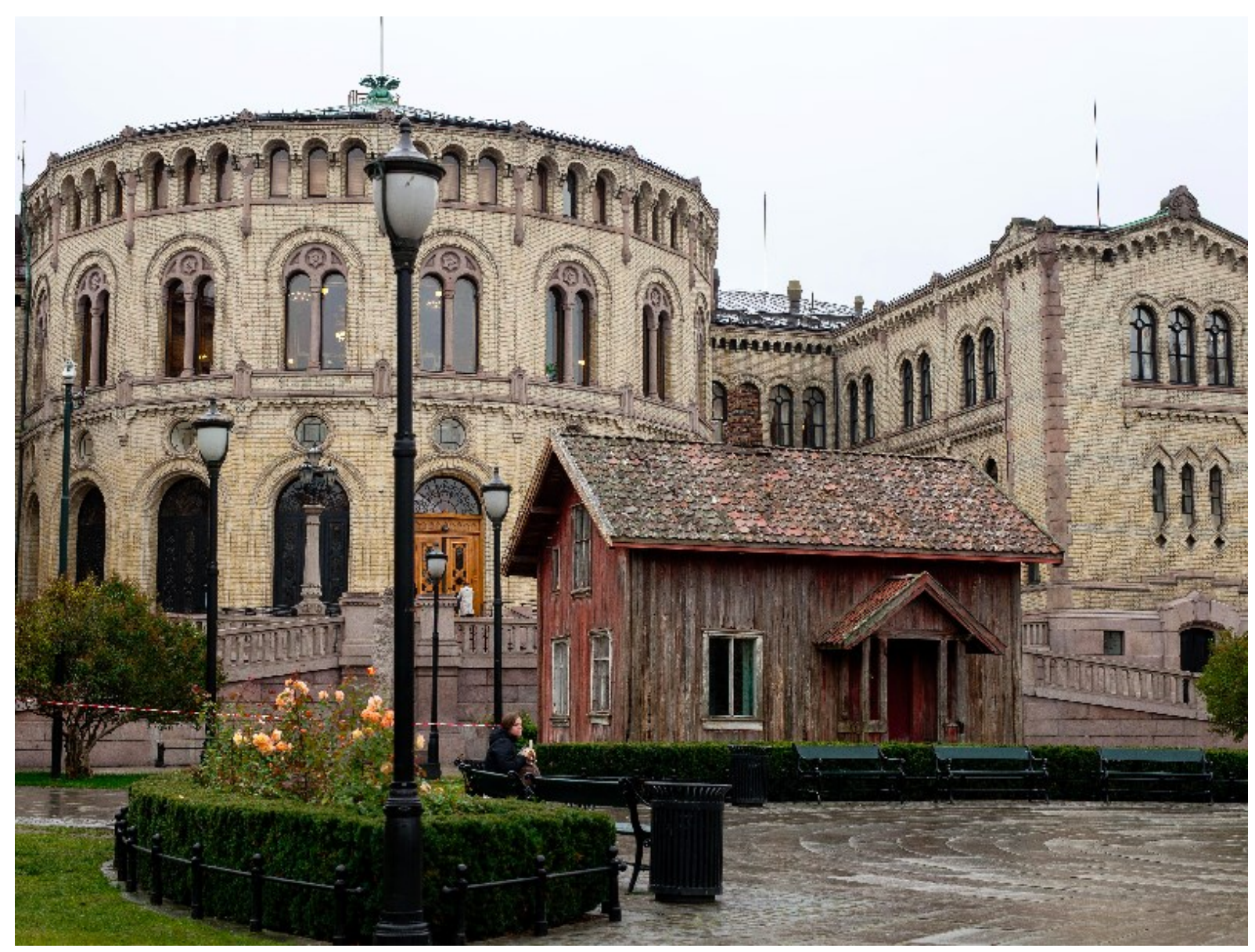

Figure 1: Marianne Heske, House of Commons in front of Norway's House of Representatives. (Oslo Pilot, 2015) Photo: Niklas Lello @

In a recent book, The Exform, Bourriaud describes culture as an 'expulsion-machine hunting down exforms' (Bourriaud, 2016, p. 28); further asserting that 'the point where the exform emerges, constitutes an authentically organic link between the aesthetic and the political' (Bourriaud, 2016, p. X). Heske no doubt foresaw the semantic charge the new context would release in the little red house; but also the disturbance in the national narrative that the house would provoke when erected on the square just outside the parliament. The project was an aesthetic and political experiment, involving a great number of unpredictable factors, but whatever its course it would engage artist as well as audience in a process of re-interpretation generating new information. The Hobøl house, from being ex-formed as waste would 
Mikkel B. Tin. Form, exform, and information in public space.

be in-formed to embody a significant part of Norway's social, economic and political history when, during the $20^{\text {th }}$ century, the vast majority of Norwegians moved from rural districts into urban settlements, leaving behind their ancestral wooden houses across the country. The Hobøl house would challenge contemporary Norwegians' ideas of themselves, of their roots and their aspirations; but it would challenge also the ideas the parliament members might have of the Norwegians they claim to represent. Heske's project established a quite obvious relation between the parliament building and the little red house; but if this relation was perceived as an incongruence, perhaps even a confrontation of two conflicting discourses, then why so - in a regime of representative democracy?

Eidsvoll square is a small lawn just in front of the parliament building in Oslo, with two pedestrian paths crossing in its circular centre. The name Eidsvoll refers to the place north of Oslo where deputies from all parts of Norway gathered in 1814 to negotiate and approve the constitution which prepared the way for the Norwegian representative democracy. Since the square is overlooked by the national assembly, it is frequently chosen as a stage for political manifestations: people gather here to express their opinions to the deputies whom they have elected to represent them. Its situation makes the Eidsvoll square unique; yet the morphology as well as the semantics of this public space are too obvious to offer much information. Norwegians take their representative democracy as a matter of course, and for the inhabitants of Oslo the Eidsvoll square is little more than a convenient short cut.

Etymologically, metaphor means 'transfer', and when Heske transferred the little red house from the countryside to the city centre, she transferred it from one register of meaning to another. 'Moving houses means translocation of realities in which I use the houses as metaphors', says Heske (Johnsen, 2015). 'Translocation as artistic strategy creates considerable space for interpretation', says Anne-Thérèse de Ridder in a thesis devoted to Heske's work (De Ridder, 2017, p. 39). Morphologically, the little red house did appear displaced in this specific urban context. As a metaphor, constructed intentionally by the conceptual artist Marianne Heske, it turned out to be extremely prolific in meaning (De Ridder, 2017, p. 49-51). When her artwork was criticized as 'out of place' that very reproach confirmed its function as a poetical trope: As long as the little red house stood abandoned along the highway, awaiting to be demolished, it was 'in place' and redundant. It was a piece of the past bound to give way to the interests of the present. Its semantic charge was reduced to insignificance, a sign coinciding perfectly with its conventional signification. When it appeared on Eidsvolls plass, intentionally in-formed as 'out of place' and 'out of time', it compelled passers-by to make an interpretative effort and answer implicit questions 
Mikkel B. Tin. Form, exform, and information in public space.

such as: 'Which one of the two houses does most justly deserve the name of "House of Commons"'? As an exform, informed anew, it did in fact demonstrate the link between the aesthetic and the political as stressed by Bourriaud, thereby producing an exceptional amount of information.

Understood as a metaphor, Heske's little red house worked as a tactic that broke into the ideological strategy of the central power specifically, and the prosaic morphology of the urban text generally, opening 'a poetic zone' (Bourriaud, 2016, p. 85). 'Then, and only then, the metaphorical twist is at once an event and a meaning, an event that means or signifies, an emergent meaning created by language.' (Ricœur, 1991, p. 99)

\section{Conclusion}

The question that opened this article was how the disciplines of morphology, semantics and poetics, traditionally concerned with verbal texts, might prove relevant in artistic research as public art. While all kinds of artistic research deal with form and meaning, art in public space is special in as far as it is site specific. Sites can be seen as already existing texts, or contexts, in which the artists intervene. In such cases, artistic research as public art must include a morphological study of the site in which to intervene. But artistic research also needs a proper understanding of the meaning that emerges from the combination of formal elements distinctive of the site. Therefore, artistic research also needs a semantic study of the meaning communicated by the urban text in question. Last but not least, artistic research as public art depends on an artistic intervention in the chosen public context. Such intervention is meant to disturb a given order. Here, poetics provides invaluable insights into a variety of tactics to disrupt the linearity of the urban text.

We have seen that Heske's House of Commons, an example of artistic research as public art, does indeed involve a morphological, a semantic, and a poetic dimension. Morphological understanding is required of the formal specificities of the two buildings; so is semantic understanding of the meaning the buildings had in their original context. But Heske's project depends even more crucially on poetics, as it is by means of metaphor she short circuits the formal and semantic registers of these two buildings. Both Michel de Certeau and Nicolas Bourriaud describe how decontextualization and re-contextualization may inform exforms and thereby yield new information; how both form and information are more properly forming processes; and how art contributes to these ongoing transformations as it 'exposes the world's non-definitive character. It dislocates, disassembles and hands things over to 
Mikkel B. Tin. Form, exform, and information in public space.

disorder and poetry' (Bourriaud, 2016, p. 43).

\section{About the author}

Mikkel B. Tin holds a doctoral degree in phenomenology from the University of Paris XII. He has been Professor of Traditional Arts, later Professor of Philosophy of Culture at the University of South-Eastern Norway. Currently, he is Curator-in-Chief at the Drammens Museum of Art and Cultural History. In his books, mainly on marginal art and cultural history, he applies a phenomenological perspective, in combination with hermeneutics and structuralism.

\section{References}

Benveniste, Emile (1971). Problems in General Linguistics (M. E. Meek, Transl.). University of Miami Press.

Bourriaud, Nicolas (2010). Marianne Heske or the art of relocation. Marianne Heske. https://www.marianneheske.no/texts

Bourriaud, Nicolas (2016). The exform (E. Butler, Transl.). Verso.

Certeau, Michel de (1988). The Practice of Everyday Life (S. Rendall, Transl.). University of California Press.

Heske, Marianne (1984). Project Gjerdelöa. Universitetsforlaget.

Johnsen, Heidi Anne (2015, October 2). Setter opp rødmalt stue foran Stortinget. Aftenposten. http://www.aftenposten.no/osloby/byliv/Setter-opp-rodmalt-stue -foranStortinget-26075b.html

Kropf, Karl (2017). The Handbook of Urban Morphology. Wiley.

Oliveira, Vítor (2016). Urban Morphology. An introduction to the study of the physical form of cities. Springer.

Ricœur, Paul (1991). The Rule of Metaphor. Multi-disciplinary studies of the creation of meaning in language (R. Czerny et al., Transl.). University of Toronto Press.

Ridder, Anne-Therese de (2017). House of Commons. Fra rønne til ikon. En studie om materialisering av fortider (Master thesis). University of Oslo.

https://www.duo.uio.no/handle/10852/58243?show=full 
Mikkel B. Tin. Form, exform, and information in public space.

Wendt, Selene (ed.) (2010). Marianne Heske. Skira and Stenersen Museum. 